\title{
地理情報検索のためのスニペット生成法
}

\section{Snippet Generation for Geographic Information Retrieval}

\author{
$\underset{\text { Hiroyuki } \text { 浩之 }}{\text { 告A }}$ \\ 日本電信電話株式会社, NTT サイバーソリューション研究所 \\ NTT Cyber Solutions Laboratories, NTT Corporation \\ toda.hiroyukielab.ntt.co.jp \\ 安田 宜仁 \\ (同上) \\ yasuda.n@lab.ntt.co.jp \\ 奥村 学 \\ 東京工業大学, 精密工学研究所 \\ Precision and Intelligence Laboratory, Tokyo Institute of Technology \\ okuapi.titech.ac.jp \\ 松浦 由美子 \\ 日本電信電話株式会社, NTT サイバーソリューション研究所 \\ NTT Cyber Solutions Laboratories, NTT Corporation \\ matsuura.yumiko@lab.ntt.co.jp

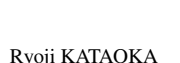 \\ (同上) \\ kataoka.ryoji@lab.ntt.co.jp
}

keywords: geographic information retrieval, summarization, snippet

\section{Summary}

Geographic information retrieval (GIR) aims at the retrieval of geographic-related documents based through the use of not only on keyword relevance but also on geographic relationships between the query and the geographic information in the texts. However, how to show search results in GIR has not been studied well, especially with regard to generating snippets that reflect the geographic part of the query. This paper proposes a novel snippet generation method. Our method first converts geographic phrases in the target text into geographic coordinates, then scores each of them according to their distance from the query using the coordinates. Next, it extracts fragments of the target text based on the distribution of the query keyword and geographic scores, and presents the combined fragments as a snippet. Evaluations are conducted with regard to two different aspects. Both attributes confirm the effectiveness of our method.

\section{1.は じめに}

サーチェンジンは人々の日常生活にとって必要不可欠 なツールとなっている半面, 乥こで利用されている技術 はまだ十分確立されているとは言えず, サーチエンジン 会社を中心とした企業やアカデミアにおいて樣々な取り 組みがなされている.

サーチエンジンに関する取り組みの一つとして, 検索結 果として提示するスニペットの生成があげられる.もし， 検索精度が十分に高ければ, スニペットを提示しなくても 検索結果は検索要求に適合するはずである. しかし, 実際 には, 任意の検索要求に対して適合する結果を得ること は困難である. 検索結果が検索要求に適合するかどうか を判定きるようなスニペットを提示することができれば, ユーザが, 目的外の検索結果を閲覧することなく, 目的と する検索結果を素早く見つけ出すことができる. また, 検 索結果の選別の手助けという観点とは別に, スニペットが 元文書中のユーザが興味を持つ情報を十分に含んでいれ
ば, 検索結果文書を閲覧しなくともスニペットのみから ユーザの望む情報を得ることができるという効果もある.

このように, スニペットを提示する目的は, (1) 検索結 果が検索要求に適合するかどうかの判定をユーザが容易 に行えるようにし, (2) 元文書中のユーザが興味を持つで あろう情報をスニペットを通じて伝達することにあると 考えられる.

初期のサーチエンジンでは, スニペットとして文書の冒 頭を提示するものが多かったが, 1990 年代後半に Google*1 が検索キーワード周辺のテキスト (いわゆる KWIC) をス ニペットとして提示するようになり, 現在の 主流となっ ている [McDonald 06]. このように, KWIC をスニペット とすることで, 検索ユーザは入力したキーワードがどの ような文脈で出現しているか理解でき, 本当に欲しい結 果であるか判断しやすくなるとの研究結果が報告されて いる [Tombros 98].

\footnotetext{
*1 http://www.google.com/
} 
一方, サーチエンジンの利用シーンの多樣化およびモバ イルデバイスを利用した Web アクセスの普及などにより， サーチエンジンへの問い合わせにおいて特定の位置に関す る問い合わせか増加している. サーチェンジンへの全アク セス数の約 $20 \%$ は特定の場所に関係する問い合わせであ ると言われており [Zhou 05, Gravano 03, Sanderson 04], 位置に関係する問い合わせに的確に答えることはサーチ エンジンにとって重要な課題となっている. この課題に対 して, 特定の場所に関する問い合わせに高い精度で検索す る事を目的とした地理情報検索技術 (GIR: Geographical Information Retrieval) カ研究されている. GIR では, 通常 のサーチェンジンのようにキーワードと文書の関係だけ で検索するのではなく, 文書中の地名表現を座標や領域 に抽象化した上で, 検索条件で示された位置 (地理クエリ) およびキーワード (内容クェリ) と, 文書との関係を用い て検索を行う. GIR によると, ユーザは特定の場所に関す る情報を的確に取得可能となる. 現在の GIR に関する研 究では, 検索精度を向上させるために多くの取り組みが 行われている [安田 08, Toda 08, Andrade 06, Li 06a, Li 06b, Markowetz 05, Vaid 05]. 一方で, GIR も基本的には テキスト情報の検索手法であり, 任意の検索要求を満た すことは不可能である. このため, 一般のサーチェンジン と同樣に, 検索結果において文書の適合性判断や元文書 の内容理解を促進するスニペットを提示することは重要 と考えられる. しかしながら, 著者らが知る限り GIRに おけるスニペット生成の問題は取り組まれていないのが 現状である.

そこで、本論文では GIR におけるスニペット生成につ いて論じる. GIR のスニペットを既存のスニペット生成 技術で生成しようとした場合には, 地理クエリの扱いが 問題となる. なぜなら，従来のスニペット生成技術はク エリ中の文字列が文書中に出現する箇所を特定して出力 するのに対し，我々か想定する GIRにおける地理クエリ は基本的には座標であるため, 文字列としてのマッチン グを行うことができないためである .このため, 従来手 法によって GIR のスニペットを生成した場合, 地理クエ リが含んでいる情報を無視することになる.あるいは, 地 理クエリを座標ではなく, 地名表現で与えるような GIR も考えられるが，GIR では文書中の地名表現を緯度経度 座標上の位置情報として抽象化して検索を行うため, 入 力された地名表現が検索結果の文書中に含まれていない 場合にはやはり地理クエリを有効に利用することはでき ない.

結果として, 従来手法によりスニペットを生成した場 合, 地理クエリと検索結果文書の関連性, たとえば想定し た範囲内にある店舗について言及している文書であるか といった判定をユーザが行うことが困難である.

そこで, 本論文では GIR に適したスニペット生成法と して, 地理クエリおよび文書中の地理表現を緯度経度座 標上の位置情報に変換し, 地理クエリと関係する地理表
現を特定した上でスニペットを生成する方法を提案する。 概要を以下に示す.

（1）文書中での地名表現を位置情報に変換する*2.

(2) 各検索結果について, 地理クエリで指定された位 置と文書中の光れ光れの地名表現が示す位置に基づ き地名表現に重み付けを行う.

（3）重み付きの地名表現と内容クエリて指定されたキー ワードの分布に基づき, テキスト断片を取得しスニ ペットとする.

以下では, まず 2 章で今回想定する GIR について述べ, 3 章で関連研究について述べる. 4 章では提案するス二 ペット生成法の詳細を示す. 5 章て評価について述べ, 最 後の 6 章でまとめる.

\section{2. 想定する地理情報検索}

1 章でも述べたように,これまでに樣々な地理情報検索 の手法が提案されているが, 本論文では安田らが取り組 んでいる “外出先で周囲に存在するサービスや店舗を探 す”検索を目的とした地理情報検索手法 [安田 08, Toda 08] を想定する.

この手法の特徵は, 多くの地理情報検索技術が「北米の 吹雪」や「ケベック州の独立運動」[Gey 06]のように比 較的大きな領域の地理クエリを対象としているのに対し て, 小さなエリアにおける距離を考慮した検索である点 である.

この手法で想定する地理クエリ $Q g$ は, 以下の二つの情 報で表現されることを前提としており，本論文でもこの 形式の地理クエリを前提とする.

- 興味の中心点: $Q g_{p}$

- 興味の中心からの許容範囲: $Q g_{d}$

ただし，これは地理情報検索の内部表現であるため, ユー ザの入力がこれに従わなければならないわけではなく, ア プリケーションによって入力される地理クエリをこの形 式に変換することで, 樣々な形式の地理クエリを利用可 能である.

例えば従来のサーチェンジンと同等のインタフェース で地理クエリの入力を求める場合, 地理クエリは「自由が 丘」や「新宿」のように文字列で入力されると考えられ る. この場合には文字列が示す代表点を中心点と考え, 許 容範囲には文字列が示す範囲を用いることが考えられる。

また, カーナビや携帯電話からのアクセスや地図イン タフェースでの入力を考えた場合には, 緯度経度等の位置 情報で表現されることが考えられる. 緯度経度情報とし て与えられた場合には, 入力された座標を中心点と考え， 許容範囲は地図で表示されてい範囲を用いること等が考 えられる.

*2 一般的な GIR システムでは検索の前処理として行われてい る. 


\section{3. 関 連 研 究}

初期のサーチエンジンでは, スニペットとして元文書の 冒頭を提示する事が多かったが, 1990 年代後半に Google が検索キーワード周辺のテキストをスニペットとして提 示するようになり, 現在の主流となっている. このス二 ペットを生成する手法はクエリ考慮型要約 (Query-biased summarization) の一種である. Tombros ら [Tombros 98] は, この要約を検索エンジンのスニペットに利用すること で, ユーザによる適合文書の選択が容易になり, 不適合文 書を選択することが減少するとの評価結果を示した. 現 在のサーチエンジンの多くでは, スニペットの生成にクエ リ考慮型要約が用いられており, 上記に示したユーザの検 索結果選択の精度向上のみでなく, 質問応答 [Dumais 02] や検索結果クラスタリング [Zamir 99] 等の検索エンジン を利用した樣々な取り組みに利用されている.

一般的にクエリ考慮型要約として利用される手法は, キーワードの出現回数や場所を利用した軽い処理を元に実 行される [Turpin 07]. 一方, より深い言語解析を行った手 法も提案されている [Chali 02, Okumura 00, Varadarajan 06]. これらの手法によると,より正確な要約をスニペッ トとして利用可能になるが, 深い言語処理を行うことで 計算コストが高くなるため, 商用のサーチェンジンでは 利用しにくい.

一方, サーチェンジンの利用シーンの増加にともない, 地理的な制約を考慮して検索を行う GIRに注目が集まっ ており,検索結果を提示する手法としても, 検索結果の文 書をリストとして提示するのではないいくつかの手法が 提案されている. 例えば, Hobona らは空間的類似度, 時間 的類似度, 意味的類似度の三つの軸を持つ 3 次元表示の 格子上に, 検索結果のドキュメントを対応付けて提示す る方法を提案している [Hobona 05]. また, Tomaszewski らは検索結果を Google Maps ${ }^{* 3}$ の対応する位置に割り当 てる方法を提案している [Tomaszewski 07].

その一方で, GIR が基本的にはテキスト情報の検索手 法であることを考慮すると, 検索結果でスニペットを示 すことは有益なものであると考えられが, 我々の知る限 り地理的制約を考慮したスニペットの生成についての先 行研究は存在しない.

また, GIR のスニペット生成では, 検索条件として入力 される地理的制約を考慮する必要があり, かつ検索結果 の文書中の文字列表記とは完全に一致しない場合もある ため, 従来のスニペット生成法を光のまま利用すること はできない.

\section{4. スニペット生成法}

まず $4 \cdot 1$ 節で我々の提案手法の元となる基本的なス二 ペット生成法について述べる. これは, 既存のスニペット

*3 http://maps.google.com/
生成法のアイデアに基づいたものである.

次に, $4 \cdot 2$ 節 において, この基本手法を GIR 向けに利 用する方法について述べる. この手法では GIR で想定さ れる地理クエリと内容クエリからなる 2 種類のクエリを を利用するために $4 \cdot 1$ 節の方法に最小限の変更を加えた 方法を述べる.

最後に, 我々の主な提案手法である GIR における地理 クエリを考慮したスニペット生成法について $4 \cdot 3$ 節で述 ベる.

\section{$4 \cdot 1$ 基本的なスニペット生成法}

本論文で想定する基本的なスニペット生成法では, 対象 とする文書からクエリ中のキーワードを含むいくつかの テキスト断片を抽出し, 光れらを組み合わせることによ りスニペットを生成する.

この方法は基本的には既存のクエリ考慮型要約の研究 である Tombros[Tombros 98] らの手法に基づくものであ る. ただし, Tombros らの提案手法が, 対象となる文書か ら文抽出 [Luhn 58, Edmundson 64] を行い, 兴の中から スニペットとして適切と思われる文を選択する文単位の スニペット生成手法であるのに対し, 提案手法では文の 代わりにテキスト断片を抽出単位としている点が異なる.

これは, サーチエンジンでの利用を考えた場合, 検索結 果の一覧表示の一部であるスニペットは, 長さの制約に 対して柔軟である必要があるためである. たとえば, GIR の一つの有効な利用状況であると考えられる携帯端末か らのアクセスを考えた場合, スニペットの長さを短くする 必要がある. このような理由から我々は, 文ではなく, テ キスト断片をスニペットの構成要素として採用する.

スニペットに利用されるべきテキスト断片の特徵は次 の二つが考えられる. 一つは, ユーザによって入力された 検索クエリに関連する文脈を提示するために, クエリに 含まれるキーワードを多く含むことである [Tombros 98]. もう一つは, キーワードが出現する前後の文脈を把握しや すくするために, テキスト断片中でできるだけキーワー ドが中心近くにあることである. これらの考えに基づく と, 位置 $x$ から始まる長さ $l$ のテキスト断片 $F(l, x)$ 中で 検索クエリ $Q c$ 中のキーワードと一致するキーワードの 集合を $T(l, x, Q c)$ とした場合, 該テキスト断片 $F(l, x)$ の スコア $S(Q c, l, x)$ は以下のように定義される.

$$
\begin{aligned}
& S(Q c, l, x) \\
& =\sum_{t \in T(l, x, Q c)}((\alpha+(1-\alpha) \\
& \left.\left.\quad \cdot\left(1-\frac{\mid \text { mid }(l, x)-k w d \_ \text {mid }(t) \mid}{l / 2}\right)\right)\right)
\end{aligned}
$$

この式中のいくつかの変数については図 1 で説明する. ここで, $\operatorname{mid}(l, x)$ はテキスト断片 $F(l, x)$ の中心の位置 を示し, $k w d \_m i d(t)$ は $F(l, x)$ 中に出現するキーワード 


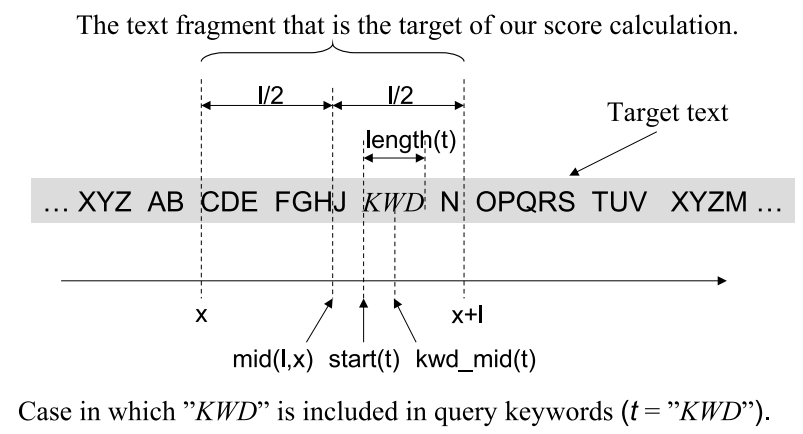

図 1 テキスト断片のスコア計算に関する用語の説明

$t$ の中心の位置を示す. これは, $k w d \_m i d(t)=\operatorname{start}(t)+$ length $(t) / 2$ として計算できる位置である. $\operatorname{start}(t)$ は キーワード $t$ の先頭位置を示し, length $(t)$ はキーワード $t$ の長さを示す. $\alpha$ は, テキスト断片中でのキーワードの 位置に基づくスコアの变動幅を調整するパラメータであ る. このパラメータにより,「キーワードがテキスト断片 の中心にある場合のスコア」に対する「キーワードがテ キスト断片の端にある場合のスコア」の割合を設定する. $\alpha$ は $0<\alpha<1$ の範囲の值を取る. より詳細な設定基準 については付録に示す.

しかし，あまりに短い断片によって構成されるスニペッ 卜は, 内容の一貫性を失いスニペットとしての有用性に欠 ける可能性がある. さらに, 単に上記のスコアの和のみを 用いてスニペットを構成しようとした場合, 何らコンテ キストを持たないテキスト中のキーワードの出現範囲の みを用いることで高いスコアを得ることになってしまう． このため, テキスト断片の長さについて二つの対策を 行う.一つはテキスト断片の最小の長さに制約を設ける ことである. これにより過度に短いテキスト断片で構成 されるスニペットの生成を防ぐ. 5 章における実験ではこ の長さ $L_{\min }$ を 20 文字とした. もう一つは, 多くのテキ スト断片から構成されるスニペットの評価値を低減させ る項を設けることである. これにより,より少ないテキス 卜断片で構成されるスニペットを優先する.

以上のテキスト断片のスコアと長さに関する制約を踏 まえたスニペットの生成手順は以下のように定める.

(1) あらかじめ決められたスニペット長 $L$ および最小 テキスト断片サイズ $L_{\min }$ を元に, 最大何個 $\left(N_{\max }\right)$ のテキスト断片からスニペットを生成するかを算出.

$$
N_{\text {max }}=\left\lfloor\frac{L}{L}{ }_{\text {min }}\right\rfloor
$$

この值は二つのパラメータ $\left(L, L_{\min }\right)$ が決定してい れば固定の値である.

（2）すべてのテキスト断片数 $N\left(N=1, . ., N_{\max }\right)$ の場 合について, スニペット候補を生成し, 兴のスコアを

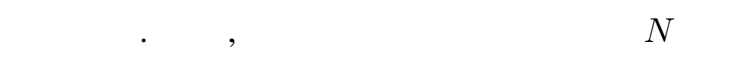
に行う処理の詳細を示す.

aテキスト断片のサイズ $L(N)$ を算出する.

$$
L(N)=\lfloor L / N\rfloor
$$

$\mathrm{b}$ すべてのテキスト断片 $F(L(N), x)$ について, (1) 式に基づきスコア $S(Q c, L(N), x)$ を算出す る. ここで $x$ は, 文書中でのテキスト断片の開始 位置を示す.

c スコア $S(Q c, L(N), x)$ の高い順に $N$ 個のテ キスト断片を集める. このテキスト断片の集合 を $X(N)$ と表す. スコアが高い順にテキスト断 片を集める際, よりスコアが高く, $X(N)$ の要素 となるテキスト断片と重なりを持つテキスト断 片は除外する.

$\mathrm{d}$ 上記で選択したテキスト断片の集合 $X(N)$ か ら,一つのスニペットを生成し，スニペットのス コアを以下の式で算出する.

$$
S d(Q c, N)=\sum_{x \in X(N)} S(Q c, L(N), x) \cdot \beta^{N}(2)
$$

$\beta$ は, 多くのテキスト断片から生成されるスニ ペットのスコアを低く見積もるための項である. $\beta$ は $0<\beta<1$ の範囲の值を取る.より詳細な 設定基準については付録に示す.

(3) 前のステップで生成したスニペット候補のうち最 もスコアの高いスニペットを生成した条件 $(N)$ を特 定し, 弚の条件で生成されたスニペットを出力する. このスニペット生成法は, 対象文書から複数サイズのテ キスト断片を全て抽出し, スコアリングする. このため, これらの手順を素朴に実装した場合, およ光元文書の文 字数 $M$ 個分のウインドウについてスコアを算出し, 弚れ らをソートするという処理を $N_{\max }$ 回行う必要がある.

また, 今回の手法では, 一つのスニペットを構成するテ キスト断片のサイズは一定であるとしているが, 弚れ光 れのテキスト断片の長さを可変として全体として定めら れた長さのスニペットを生成することも考えられる.し かし, 光のように長さに関する制約を緩めた場合, ナップ ザック問題に帰着され, 最適解を求めることは計算量的 にコストが高い. 近似解を得る方法も提案されているが [McDonald 07], 現状の計算リソースを考えた場合, 多く のアクセスに対応しなければならないサーチェンジンの スニペット生成として使うには現実的ではない.このこ とから, 我々の手法では一つのスニペットを構成するテキ スト断片のサイズは一定としている. 


\section{$4 \cdot 22$ 種類の制約を考慮するためのスニペット生成手法 の変更}

本節では, GIR が受け付けるクエリ,すなわち内容クエ リと地理クエリに対応させるために, 上記のスニペット生 成法を変更する方法について述べる. このような 2 種類の クエリを受け付ける検索システムのスニペットとしては, 内容に関するキーワードもしくは位置に関するキーワー ドの片方ではなく, 両方を含むことか望ましい. この考え は, 従来のスニペット生成法において, 異なるキーワード を含んでいるスニペット候補に高いスコアを与えるスニ ペットの生成 [Turpin 07] と類似している.

この考えを満たすスニペットを生成するには, $4 \cdot 1$ 節の 手法に一つ問題がある. この方法は単に高いスコアのテ キスト断片を採用するため, 片方のクエリに関係するキー ワードしか含んでいないスニペットを選択する可能性が あるからである.

弚こで, $4 \cdot 1$ 節の基本生成手法における $2 \mathrm{c}$ ステップに 変更を加える. 変更内容は以下に示す通りである.

・求めたスコアに関係なく,内容クエリに関連した文 字列と地理クエリに関連した文字列の双方を含む断 片を優先する. このような断片が複数存在する場合 はスコアの高いものを優先する.

・双方の文字列を含む断片がない場合には, 内容クエ リに関連した文字列を含む断片と,地理クエリに関 連した文字列を含む断片を交互に選択する. 交互に 選択する際, スコアが高い断片を最初に選択する.

\section{$4 \cdot 3$ 地理クエリを座標として扱うスニペット生成法} 本節では, 我々ガ提案するスニペット生成法を述べる. 主な提案は以下の通りである.

提案 1 地理クエリと関連する地名表現を利用したスニ ペットを生成する.

提案 2 地理クエリとの関連性に応じて地名表現を優先 度付けし,より優先度の高い地名表現を含むテキス 卜断片を優先する.

以下では, まず文書中の地名表現を地理的な座標とし て扱うための前処理について示す. 谷の後に我々の提案 手法の詳細について述べる.

\section{$\S 1$ 前処理}

文書中の地名表現を地理的な座標として扱うため, 文 書から地名表現を抽出するジオパーサおよび地名表現に 対して緯度経度などの位置情報を割り当てるジオコーダ を利用する [Clough 05]. しかしながら，自然言語を対象 とする以上，本質的にあいまいな表現を含む場合もあり， これらの処理において誤りを含むことは不可避である.こ の結果として, 文書では想定していない位置情報を文書 と関連付けてしまうことがある.

一方, ある文書が特定の地理的範囲について言及して いるのであれば, 光れらの地理的範囲は文書中で互いに 近い場所を示す地名表現によって表現されると考えられ
る. また, このことからジオパーサやジオコーダのエラー により割り当てられた座標はこれら特定の地理的範囲か ら大きく外れた場所を示していると考えられる. この考 えに基づき, 我々は座標情報を元に文書中の地名表現を グループ化し, 文書中の主題である地理的範囲を特定す ることで, 光の地理的範囲に含まれない地名表現をノイ ズとして除去することを考えた.

つまり,この処理の目的は, 検索条件に関連付けたス二 ペットを生成するために検索条件の地理クエリと関連性 の薄い地名表現を除去することにある. 処理の概要を図 2 に示す.

この地名表現のグループ化には, 最短距離法に基づく クラスタリングを利用した. 以下に各文書について行う 処理の手順を示す.

(1) 該文書中の全ての地名表現を単一要素のクラスタ とする.

(2) 互いの要素間の最短距離をクラスタ間の距離とし て,もっとも近いクラスタペアを併合する.

(3) 上記のステップを全てのクラスタ間の距離が閾値 $T_{c}$ を越えるまで繰り返す.

ここで, 要素間の距離には地名表現の代表点間のユー クリッド距離を用いる. ただし, 地名表現が表す住所 ${ }^{* 4}$ 間 に包含関係がある場合, 距離は 0 とする. 閾値 $T_{c}$ は, 地理 クエリの範囲条件 $Q g_{d}$ の 2 倍の長さとする. これは, 地 理クエリの範囲条件は, 利用者が谷の範囲内は同一の地 理的範囲であると認識している範囲を示唆していると考 えた為である。

クラスタ作成後, 要素の多いクラスタから順に選び, 選 択されたクラスタの要素数の累計が, ページ全体に含まれ る地名表現の数に対して事前に与えられた割合 $T_{e}$ を越 えるまでのクラスタを選択する. 光してこれら選択され たクラスタ内の地名表現を以後のプロセスで利用し，光 れ以外の地名表現はノイズとして除去する.つまり, 大き なクラスタに属する地名表現のみをスニペット生成に利 用する.

以下に処理の例を挙げる. 今回の評価で利用したテスト セットに含まれる一つの文書に四つの地名表現(「福岡」 「福岡市南区」「福岡」「中央区」) が含まれた文書が存在

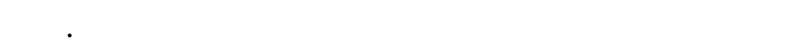
岡県福岡市南区」「福岡県」「東京都中央区」である. 文書 の内容から考えると最後の地名表現「中央区」は「福岡 県福岡市中央区」のことを示しており，上記の「中央区」 のジオコード結果は間違いである. 前述のクラスタリン グを行う事で, 前者三つが一つのクラスタとなり,「中央 区」が要素 1 の別のクラスタとなる. 光して大きいクラ スタ中の地名表現のみを採用する事で, ジオコードに失 敗した「中央区」は除去される.これによってこの文書 を福岡県に関係し, 東京都中央区には関係しない文書と

\footnotetext{
*4 ジオコーダによって正規化された住所が得られるため, 弚れ を利用する。
} 


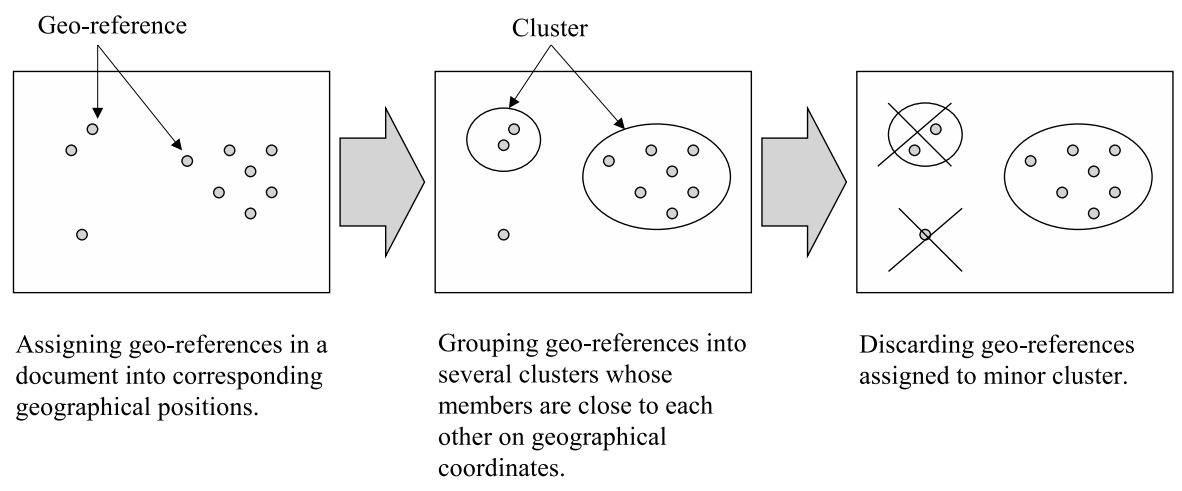

図 2 前処理の概要

して扱う事が可能となる.

一般的に GIR システムでは, 以上示したジオパージン グ, ジオコーディングおよびノイズ除去は前処理として 行われ，検索が行われる際にはこれらの情報を利用して スニペットを生成する.

§ 2 スニペット生成に利用する地名表現の選択

まず主な提案のうち一つ目について示す. 我々は, スニ ペットを生成するために有益な地名表現は以下の条件を 満たすものであると考えた.

条件 地名表現が示す位置が, 地理クエリで示される領

域に含まれるか, 近接していること.

ここで, 我々はユーザが地理クエリで指定する中心点 $Q g_{p}$ から範囲条件 $Q g_{d}$ の 2 倍以内におさまる範囲を地 理クエリと関連性のある範囲であると考え, この範囲に 含まれる場所を示す地名表現を，上記条件を満たす地名 表現であると見なし，スニペットの生成に利用する.

\section{$\S 3$ 地名表現の優先度付け}

次に主な提案のうち二つ目について示す.この提案の モチベーションは, 地理クェリとより高い関連性のある 地理表現を優先的に提示した方がユーザにとってわかり やすいスニペットになると考えた所にある.

地理クエリと文書中の地名表現の関連性の強さはいく つか考えられるが, ここでは 2 章で述べた “外出先で周囲 に存在するサービスや店舗を探す”ような地理情報検索 を実現するために重要であると考えられる以下の二つの 条件に基づき地名表現の優先度を定義する.

・地理クエリで示される領域からより近い領域を示し ていること

・より特定された領域を示していること

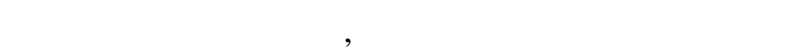
表現が示す場所の距離」および「地名表現によって示さ れる地理的範囲」によって評価することができる. これ らを元にした地名表現 $e$ と地理クエリ $Q g$ の関係の強さ $W(e)$ は以下の式で算出する.

$$
\begin{aligned}
& W(e)=\operatorname{Closeness}(Q g, e) \cdot \operatorname{Specificity}(e) \\
& \text { Closeness }(Q g, e)=1 / \operatorname{dist}(Q g, e) \\
& \text { Specificity }(e)=1 / \text { extent }(e)
\end{aligned}
$$

$\operatorname{dist}(Q g, e)=\left\{\begin{array}{c}d_{\text {inner }} \\ \left(Q g_{p} \text { is inside } e \text { 's extent }\right) \\ d_{\text {inner }}+d_{\text {edge }}(e, Q g) \\ \left(Q g_{p} \text { is outside } e \text { 's extent }\right)\end{array}\right.$

ここで $d_{i n n e r}$ は十分小さな定数であり, 地理クエリの中 心点 $Q g_{p}$ が地名表現 $e$ で示される範囲の中である場合 の距離として設定する. また, $d_{e d g e}(e, Q g)$ は, 地名表現 $e$ が含意する領域の境界線から地理クエリの中心点 $Q g_{p}$ までの最短距離を示す. また, $\operatorname{extent}(e)$ は地名 $e$ が表現 する範囲の広さであり,地名 $e$ が表現する経度方向の長 さと緯度方向の長さの積である.

$\S 4$ テキスト断片のスコア計算

上記 $4 \cdot 3 \cdot 2$ 節で示した手法で選択された地名表現と $4 \cdot 3 \cdot 3$ 節で示した光の重み付けを利用し, スニペットの候 補となるテキスト断片の評価を行う. 地理クエリ $Q g$ に 対するテキスト断片のスコア $S_{g}(Q g, l, x)$ は以下の式で 定義される. このスコアは, (1) 式に地名表現の重みを考 慮したものである.

$$
\begin{aligned}
& S_{g}(Q g, l, x) \\
& =\sum_{e \in E(l, x, Q g)}(W(e) \cdot(\alpha+(1-\alpha) \\
& \left.\left.\quad \cdot\left(1-\frac{\mid \text { mid }(l, x)-k w d \_m i d(e) \mid}{l / 2}\right)\right)\right)
\end{aligned}
$$

$\alpha, l, x, \operatorname{mid}(l, x), k w d \operatorname{mid}(e)$ は (1) 式で示される意味 と同樣である. $E(l, x, Q g)$ は, 4·3·2 節の手法により選 択された地名表現のうち, 対象のテキスト断片 $F(l, x)$ 中 に含まれる地名表現の集合である. また $e$ は光の集合の

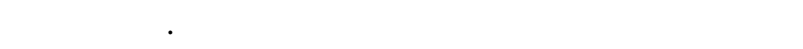
$S^{\prime}(Q c, Q g, l, x)$ は以下の式で算出される.

$$
S^{\prime}(Q c, Q g, l, x)=S(Q c, l, x)+S_{g}(Q g, l, x)
$$

$4 \cdot 1$ 節で示したスニペット生成手順の $S(Q c, l, x)$ をこ の $S^{\prime}(Q c, Q g, l, x)$ で置き換える. 評価では, 提案手法と して二つのバリェーションを利用する. 一つは上記 $1 つ$ 目の提案のみを利用した手法であり, この場合, $W(e)$ は 定数とする. もう一つは上記で示した両方の提案を利用 した手法である. 


\section{5. 評価}

GIR におけるスニペット生成において, 提案手法の有効 性を確認するため, 実際の GIR 検索の結果と組み合わせ たスニペットの出力に対して, 被験者による評価を行った.

\section{$5 \cdot 1$ 評 価 手 法}

提案法とともに, スニペット生成における検索条件中の 地理クエリの利用法がスニペットの質にどのような変化 をおよぼすかを評価するため, 以下の 2 種類を比較手法 とした.

KWD_ONLY 地理クエリを利用せずに，内容クエリの キーワードのみを用いて, $4 \cdot 1$ 節で述べる基本手法に よってスニペットを生成する手法.

AS_STRING KWD_ONLY に4·2 節に述べる変更を加 え, 地理クエリの文字列表現と一致する地名表現を 考慮する手法.

評価で用いる提案法は地名表現の重みに関する取り扱い 方の異なる以下の 2 種類である

AS_COOR 提案手法の一つであり, 4.3 節で示した提案 1 のみを利用したもの. 地理クエリと関連するすべて の地名表現を均一な重みで利用する手法.

AS_COOR_D 提案手法の一つであり, $4 \cdot 3$ 節で示した 提案 1 および 2 を利用したもの. 地理クェリとの関 連性に応じて地名表現を優先度付けし利用する手法.

\section{2 評 価 条 件}

\section{$\S 1$ 評価タスク}

クエリを考慮しない汎用の要約とは異なり, 検索結果 のスニペットには, 弚の結果を見てユーザが当該文書を閲 覧するかどうかを判断するという明確な目的がある. 光 のため, 検索結果のスニペットの評価は, スニペット光の ものを内的 (intrinsic) に評価するのではなく, スニペット がユーザの正しい判断に結びついているかに基いた外的 (extrinsic) な評価を行う.

1 章において, スニペット提示の目的として挙げた, (1) 検索結果か検索要求に適合するかどうかの判定をユ一 ザが適切に行えるようにする

(2) 元文書中のユーザが興味を持つであろう情報をスニ ペットを通じて伝達する

という二つの側面を評価するために, 評価は以下の二つ のタスクで構成される.

指示性評価 スニペットが, ユーザの検索要求に適合する 検索結果を選別する手助けをしているかどうかを評 価するためのタスクである.

被験者はスニペットを元に検索結果中の各文書を 閲覧すべきか否かを判定する. スニペットが十分指 示的であれば, スニペットを元に決定された閲覧文書 は適合しているはずであり, 結果としてユーザは適 合文書を選別しやすくなるはずである. 一方, 不適合
表 1 指示性評価基準

表 2 に示される判定規準による適合文書を求めていた 場合に, 当該スニペットの元文書を閲覧すべきか否か.

\begin{tabular}{cl}
\hline スコア & 基準 \\
\hline 0 & 閲覧すべきではない \\
1 & 閲覧すべき \\
\hline
\end{tabular}

表 2 適合性判定規準

スニペット中で, 内容クエリに関係する商品やサービ スを扱う店舗もしくは組織のうち, 地理クエリで指定 された場所に存在するものが言及されているか.

\begin{tabular}{cl}
\hline スコア & 基準 \\
\hline 0 & 該当する情報について記述がない \\
1 & 該当するる情報について述べているが, スニペッ \\
& トの主題ではない \\
2 & $\begin{array}{c}\text { 該当する情報について述べられており, スニペッ } \\
\quad \text { rの主題である }\end{array}$ \\
\hline
\end{tabular}

文書をユーザが適切に選別できれば, 無駄な文書を 閲覧するという手数を減らすことができる.このた め,評価結果にはこれら二つの結果を示す.

被験者への教示内容および判定基準を表 1 に示す. 適合性判定の一致 スニペットが, 元文書中のユーザが興 味を持つであろう情報を十分伝達しているかを評価 するためのタスクである.

まず,被験者はスニペットのみを閲覧して検索結 果としての適合性判定を行う. 適合性判定の手順は, 安田ら [安田 08] が示している GIR の適合性判定手 順に準じる.このスニペットのみに対する適合性判 定結果と, 元文書を閲覧して行われた検索結果に対 する適合性判定結果を比較する. 実験ではスコアが 1 以上のものを適合文書として扱った.

被験者への教示内容および判定基準を表 2 に示す. サーチエンジンのためのスニペットであることを考慮 し,評価結果にはマクロ平均で算出した値を示す.これは, マクロ平均によって, 個々の検索トピック毎の挙動を元に した考察ができると考えた為である。

$\S 2$ 評価セットとパラメータ条件

評価ではブログサービスの「goo ブログ*5」から取得 したブログ記事コーパスに対して検索を行い, 得られた 結果のテキスト群を評価セットとして利用した 。

ブログ記事コーパスは，ブログ著者がブログサイトを 作成する段階で，ブログサイトの主な記事の内容を「地 域情報」もしくは「食べ歩き」とした記事である．この コーパスのブログ記事は, 約 19,000 人の著者によって書 かれた約 30 万のブログ記事である .

評価セットは, このコーパスに対して, 表 3 に示した検 索トピックで検索を行い, 検索結果のプーリングを行った ものである*6.プーリングの対象は [安田 08] において検

*5 http://blog.goo.ne.jp/

*6 すべての検索トピックはユーザが近くにある店舗やサービス 
表 3 検索トピック

\begin{tabular}{l|l|l}
\hline \multirow{2}{*}{ 地理クェリ } & \multicolumn{1}{|c|}{ 興味の中心点 } & 札幌駅, 東京駅, 梅田 $($ 大阪駅) \\
\cline { 2 - 3 } & 興味の中心からの許容範囲 & $1 \mathrm{~km}$ \\
\hline \multirow{2}{*}{ 内容クエリ } & $\begin{array}{l}\text { カレー, ラーメン, ハンバーグ, ケーキ, コーヒー, } \\
\text { 紅茶, 焼肉, うどん }\end{array}$ \\
\hline
\end{tabular}

索結果評価を行った際に利用した手法で検索された光れ

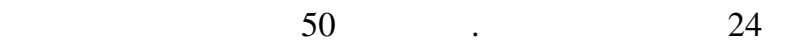
索トピック分を合わせて 1921 件であり, 弚のうち 464 件 が適合文書, 1457 件が不適合文書である.

また, AS_STRING の場合には, 表 3 で興味の中心点と して示した文字列と一致する地名表現をスニペット生成 で利用した ${ }^{* 7}$.

サーチエンジンの結果提示に利用するスニペットは元 文書のサイズにかかわらず一定の大きさである必要があ る. このため, 本評価ではスニペットの長さは, 汎用の要 約でしばしば用いられるような圧縮率として指定するの ではなく,最大スニペット長として与える.

最大スニペット長については 2 種類の長さについて評 価を行った. というのも, GIR ではユーザの所在が重要な 情報になることから, PC に加えて, GPS などによる位置 情報を取得可能な携帯端末からの利用も考えられるから である. PCなどの広いディスプレイを想定した相対的に 長めのスニペット長として 120 文字, PDA や携帯電話な どの狭いディスプレイを想定した相対的に短いスニペッ 卜長として 40 文字とした. これらは Yahoo!*8や Google などの通常の検索サービスと同等になるように決定した.

$4 \cdot 3 \cdot 1$ 節で示したノイズとなる地名を除去するための クラスタリングの閾值 $T_{c}$ は地理条件の範囲条件の 2 倍 とした.これは, 範囲条件で指定された検索対象範囲中の 任意の 2 点は同一の場所と考えられることに基づいてい る. 4.3.1 節で示した閾値 $T_{e}$ は, ノイズとなるジオコー ド結果がどの程度正確に除去されるかを判定した予備実 験の結果に基づき 0.75 に決定した. また, 予備検討の結 果, テキスト断片中のキーワードの位置に関するパラメー タ $\alpha=0.9$, スニペット中の断片数に応じたスコアの減衰 パラメータ $\beta=0.9$ とした.

\section{$\S 3$ 被験者}

被験者数は 8 人である. 弚れ光れのスニペットは一人 の被験者により，スニペットが示す文書の適合性および 指示性評価について判定される. 被験者はランダムに選 択されるスニペットとスニペットを生成した検索トピッ クの組み合わせを取得し, 判定を行う.ただし, 同一の被 験者が同一の文書から生成されたスニペットを複数判定 することは行わない. これは一つの文書に関する複数の スニペットを閲覧することによって, 被験者が文書全体を 想定できるようになることを防ぐためである. また,一つ

を探している状況を想定している.

*7 梅田 (大阪駅) ガ検索条件の場合には, “梅田”と“大阪駅” の

両方の表記を扱った

*8 http://www.yahoo.com/
表 4 指示性の評価結果 (適合文書に到達できるかどうか)

\begin{tabular}{|c|c|c|c|}
\hline 手法 & 適合率 & 再現率 & $\mathrm{F}$ 值 \\
\hline \multicolumn{4}{|c|}{ Short } \\
\hline AS_COOR_D & 0.6378 & 0.6418 & $0.6142(* *, \# \#)$ \\
\hline AS_COOR & 0.5952 & 0.4960 & $0.5315(* *$,\#\#) \\
\hline AS_STRING & 0.6710 & 0.2479 & $0.3071(* *)$ \\
\hline KWD_ONLY & 0.3382 & 0.0797 & 0.1195 \\
\hline \multicolumn{4}{|c|}{ Long } \\
\hline AS_COOR_D & 0.6638 & 0.6243 & $0.6389(* *, \# \#)$ \\
\hline AS_COOR & 0.6621 & 0.6166 & $0.6305(* *, \# \#)$ \\
\hline AS_STRING & 0.6368 & 0.4091 & $0.4673(* *)$ \\
\hline KWD_ONLY & 0.6525 & 0.2193 & 0.3110 \\
\hline
\end{tabular}

AS_STRING との間で有意な精度向上が見られた場合を示す. 検定 にはウィルコクソン符号付き順位検定（危険率 5\%) を利用. 特に** および\#\#は $p<0.01$ を示す.

の文書から同一のスニペットが生成された場合には判定 は 1 回のみとした.

\section{$5 \cdot 3$ 指示性評価の結果}

表 4 に, スニペットを閲覧したユーザが適合文書へ到達 できるかどうかに関するスニペットの指示性評価結果を示 す.また, 表 5 に不適合文書を避けることに関する指示性 評価の結果を示す. 表 4 から, 提案手法は $\mathrm{F}$ 值において比 較手法を大きく上回る評価値を示している. AS_STRING の評価値は提案手法と比較して大きく低下しており, 単 純に代表的な地名表現を利用するのみでは良い結果を得 られないことがわかる. 表 5 でも提案手法が比較手法を 上回る F 值を示すことがわかるが, 短いスニペットを利 用した実験では提案手法と比較手法の間で有意差は確認 できなかった.

表 4, 表 5 より, 提案法のうち地名表現の優先度を考慮 した手法では, スニペット長にかかわらず高い F 值を示 すことがわかる. しかし地名の優先度を考慮しない提案 法および比較手法はスニペット長の変化による $\mathrm{F}$ 值の差 が大きい. これは, 地名の優先度を利用することで,より 有益な地名表現が選択でき, 短いスニペット長の場合に も指示性の高いスニペットが生成できていることを示し ている.

\section{4 適合性判定一致率の結果}

表 6 に適合性判定一致率の評価結果を示す. この評価 では, 元の文書を読んだ場合の適合性判定結果と, 生成し 
表 7 適合性判定一致率評価の分割表

\begin{tabular}{l|r|r|r|r|r|r}
\hline 手法 & TP & TN & FP & FN & 一致率 (マイクロ平均) \\
\hline \multicolumn{7}{c}{ Short } \\
\hline AS_COOR_D & 241 & 1364 & 93 & 223 & 0.8355 \\
AS_COOR & 208 & 1376 & 81 & 256 & 0.8246 \\
AS_STRING & 101 & 1402 & 55 & 363 & 0.7824 \\
KWD_ONLY & 25 & 1447 & 10 & 439 & 0.7663 \\
\hline \multicolumn{7}{|c}{ Long } \\
\hline AS_COOR_D & 274 & 1370 & 87 & 190 & 0.8558 \\
AS_COOR & 270 & 1371 & 86 & 194 & 0.8542 \\
AS_STRING & 197 & 1395 & 62 & 267 & 0.8287 \\
KWD_ONLY & 96 & 1434 & 23 & 368 & 0.7965 \\
\hline
\end{tabular}

表 5 指示性の評価結果 (不適合文書を避けられるかどうか)

\begin{tabular}{l|r|r|r}
\hline 手法 & 適合率 & 再現率 & F 值 \\
\hline \multicolumn{4}{|c}{ Short } \\
\hline AS_COOR_D & 0.8724 & 0.8744 & 0.8699 \\
AS_COOR & 0.8529 & 0.8918 & 0.8694 \\
AS_STRING & 0.7883 & 0.9483 & 0.8552 \\
KWD_ONLY & 0.7659 & 0.9865 & 0.8540 \\
\hline \multicolumn{4}{c}{ Long } \\
\hline AS_COOR_D & 0.8783 & 0.8953 & $0.8854(*)$ \\
AS_COOR & 0.8791 & 0.9068 & $0.8914(* *)$ \\
AS_STRING & 0.8275 & 0.9328 & 0.8741 \\
KWD_ONLY & 0.7903 & 0.9664 & 0.8637 \\
\hline
\end{tabular}

アスタリスクは, KWD_ONLY との間で有意な精度向上が見られた 場合を示す. 検定にはウィルコクソン符号付き順位検定 (危険率 $5 \%)$ を利用. 特に**は $p<0.01$ を示す.

\begin{tabular}{l|r} 
表 6 適合性判定一致率の評価結果 \\
\hline 手法 & 一致率 \\
\hline \multicolumn{2}{c}{ Short } \\
\hline AS_COOR_D & $0.8355(* *, \# \#)$ \\
AS_COOR & $0.8252(* *, \# \#)$ \\
AS_STRING & 0.7798 \\
KWD_ONLY & 0.7648 \\
\hline \multicolumn{2}{c}{ Long } \\
\hline AS_COOR_D & \multicolumn{1}{|c}{$0.8540(* *$,\#) } \\
AS_COOR & $0.8523(* *, \# \#)$ \\
AS_STRING & $0.8261(* *)$ \\
KWD_ONLY & 0.7942 \\
\hline
\end{tabular}

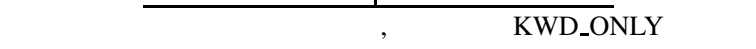
AS_STRING との間で有意な精度向上が見られた場合を示す. 検定 にはウィルコクソン符号付き順位検定 (危険率 5\%) を利用. 特に*** および\#\#は $p<0.01$ を示す.
表 8 適合性判定一致率評価分割表の説明

\begin{tabular}{|c|c|c|c|}
\hline & \multicolumn{2}{|c|}{ スニペットによる適合性判定 } \\
\hline & & 適合 & 不適合 \\
\hline \multirow{2}{*}{$\begin{array}{c}\text { 元文書による } \\
\text { 適合性判定 }\end{array}$} & 適合 & $\mathrm{TP}$ & $\mathrm{FN}$ \\
\hline & 不適合 & FP & $\mathrm{TN}$ \\
\hline
\end{tabular}

たスニペットを読んだ場合の適合性判定結果の一致率を 評価している.

表 6 から, 提案法がすべての条件において, 比較手法よ り高い一致率を示し, 弚の差が有意であることがわかる. AS_STRING の結果をみると, スニペット長が長い条件で は比較的良い結果を残しているが, スニペット長が短い条 件では提案手法と比較して評価值が大幅に低下している.

次に, 検索トピック単位だけでなく, 各検索文書に対す るスニペットの善し悪しに関して考察を行うため, 表 7 に 実験結果の分割表を示す. この表中の TP, TN, FP, FN の 意味は表 8 に示される. なお, 表 6 中の值は, 弚れ光れの 検索卜ピックごとの評価值を平均したマクロ平均の值で ある. よって, 表 7 を元に計算したマイクロ平均とは多少 ずれがある. 表 7 から, 今回の評価データでは不適合文書 が多く,すべての文書を不適合と判定しても約 76\%(マイ クロ平均) 程度の一致率となる. このことを考慮すると, 比較手法の AS_STRING と比べて提案手法の一致率の精 度向上幅は, 長いスニペット長の条件で $30 \%$ から $40 \%$, 短 いスニペット長の場合には 2 から 3 倍にもなり, 個々の スニペット単位で評価を行った場合でも提案手法の有効 性が確認できる.

\section{$5 \cdot 5$ 出力例とその分析}

提案手法のうち AS_COOR_D と比較手法のうち AS_

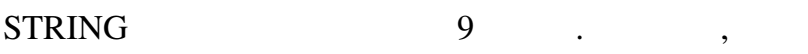
手法では適切なスニペットが生成できないのに対し, 提 案手法が効果的に動作する場合と, 弚の逆に提案手法が かえって不適切なスニペットを生成してしまう場合の典 型例である. 表中, どちらのいずれの文書も適合性判定の 結果適合文書とされた文書である. 
まず，「うどん札幌」をクエリとした結果について,比 較手法では文書がどういう地理的な位置を述べている可 能性があるのか分からないため, 被験者によって「閲覧す べきでない」と判定されているのに対し, 提案手法では, 内容クエリと地理クエリ双方と文書の関連を知ることが できるたため適切に「閲覧すべき」判定されていること が分かる.

次に，「ハンバーグ 札幌」をクェリとした結果につい て, 比較手法では結果として「道庁最上階」という文字 列が含まれていたため被験者は地理クエリとの関連を知 ることができた. 一方で, 提案手法では地理クエリと関連 のある表現をスニペットに含めることができなかったた め, 「閲覧すべきでない」と判定されている. これは, 提 案手法が地名表現として取り扱う対象が, ジオコーダに よって緯度経度を割り振ることに成功した部分に限られ ているため, ジオコードをすることができなかった「道庁 最上階」を地名表現として取り扱えなかったことに起因 する. さらに, 提案法では, スコアと無関係に内容クエリ に関連した断片と地理クエリに関連した断片を交互に選 択するため,クエリとの関連の低い断片が含まれてしまっ ている.

\section{6. ま と め}

本論文では GIRにおける新しいスニペット生成法を提 案した. 主な特徵は GIR の検索クエリに含まれる地理制 約と関連性の高い地理表現を利用することである. スニ ペットの指示性に関する評価および適合性判定の一致率 では, 提案法によるスニペットが, 比較手法と比べて高い 評価値を得ることを確認した.

$5 \cdot 5$ 節での議論の通り, 提案法では断片のスコアによら ず内容クエリに関連した断片と地理クエリに関連した断 片を交互に選択するため, 結果としてクェリとの関連の 低い断片が含まれてしまうことがある. 性質の異なる 2

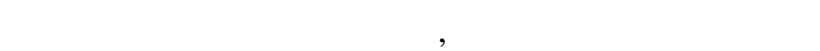
した断片の選択基準は今後の課題である.

サーチエンジンへのスニペット生成の導入を考えた場 合, スニペット生成の計算量がもう一つのポイントとな る. この点を考慮し, 我々の手法では表層的な文字列比較 のみを利用した手法としたが, 今回の提案法を素朴に実 装した場合の処理コストは小さくない. 今後, この点につ いて対処するため, スニペット生成の効率化について検 討することを考えている.

\section{$\diamond$ 参 考 文 献 $\diamond$}

[Andrade 06] Andrade, L. and Silva, M. J.: Relevance Ranking for Geographic IR, in GIR (2006)

[Chali 02] Chali, Y.: Generic and Query-Based Text Summarization Using Lexical Cohesion, in AI '02: Proceedings of the 15th Conference of the Canadian Society for Computational Studies of Intelligence on Advances in Artificial Intelligence, pp. 293-302, London,
UK (2002), Springer-Verlag

[Clough 05] Clough, P.: Extracting metadata for spatially-aware information retrieval on the internet, in GIR '05: Proceedings of the 2005 workshop on Geographic information retrieval, pp. 25-30, New York, NY, USA (2005), ACM

[Dumais 02] Dumais, S., Banko, M., Brill, E., Lin, J., and Ng, A.: Web question answering: is more always better?, in SIGIR '02: Proceedings of the 25th annual international ACM SIGIR conference on Research and development in information retrieval, pp. 291-298, New York, NY, USA (2002), ACM

[Edmundson 64] Edmundson, H. P.: Problems in automatic abstracting, Commun. ACM, Vol. 7, No. 4, pp. 259-263 (1964)

[Gey 06] Gey, F., Larson, R., Sanderson, M., Bischoff, K., Mandl, T., Womser-Hacker, C., Santos, D., and Rocha, P. eds.: GeoCLEF 2006 : the CLEF 2006 Cross-Language Geographic Information Retrieval Track Overview (2006)

[Gravano 03] Gravano, L., Hatzivassiloglou, V., and Lichtenstein, R.: Categorizing web queries according to geographical locality, in CIKM '03: Proceedings of the twelfth international conference on Information and knowledge management, pp. 325-333, New York, NY, USA (2003), ACM

[Hobona 05] Hobona, G., James, P., and Fairbairn, D.: An evaluation of a multidimensional visual interface for geographic information retrieval, in GIR '05: Proceedings of the 2005 workshop on Geographic information retrieval, pp. 5-8, New York, NY, USA (2005), ACM

[Li 06a] Li, Y., Moffat, A., Stokes, N., and Cavedon, L.: Exploring Probabilistic Toponym Resolution for Geographical Information Retrieval, in GIR (2006)

[Li 06b] Li, Z., Wang, C., Xie, X., Wang, X., and Ma, W.-Y.: Indexing implicit locations for geographical information retrieval, in GIR (2006)

[Luhn 58] Luhn, H. P.: The automatic creation of literature abstracts, IBM Journal of Research and Development, Vol. 2, No. 2, pp. 159165 (1958)

[Markowetz 05] Markowetz, A., Chen, Y.-Y., Suel, T., Long, X., and Seeger, B.: Design and Implementation of a Geographic Search Engine, in Doan, A., Neven, F., McCann, R., and Bex, G. J. eds., WebDB, pp. 19-24 (2005)

[McDonald 06] McDonald, D. M. and Chen, H.: Summary in context: Searching versus browsing, ACM Trans. Inf. Syst., Vol. 24, No. 1, pp. 111-141 (2006)

[McDonald 07] McDonald, R.: A Study of Global Inference Algorithms in Multi-document Summarization., in Amati, G., Carpineto, C., and Romano, G. eds., ECIR, Vol. 4425 of Lecture Notes in Computer Science, pp. 557-564, Springer (2007)

[Okumura 00] Okumura, M. and Mochizuki, H.: Query-biased Summarization Based on Lexical Chaining, Computational Intelligence. Vol. 16, No. 4, pp. 578-585 (2000)

[Sanderson 04] Sanderson, M. and Kohler, J.: Analyzing geographic queries, in GIR '04: Proceedings of SIGIR2004 Workshop on Geographic Information Retrieval, ACM Press (2004)

[Toda 08] Toda, H., Yasuda, N., Matsuura, Y., and Kataoka, R.: Incorporating place name extents into Geo-IR ranking, in CIKM '08: Proceedings of the seventeenth international conference on Information and knowledge management, pp. 1489-1490, New York, NY, USA (2008), ACM

[Tomaszewski 07] Tomaszewski, B. M., Pan, C.-C., Mitra, P., and MacEachren, A. M.: Facilitating situation assessment through gir with multi-scale open source web documents, in GIR '07: Proceedings of the 4th ACM workshop on Geographical information retrieval, pp. 95-96, New York, NY, USA (2007), ACM

[Tombros 98] Tombros, A. and Sanderson, M.: Advantages of Query Biased Summaries in Information Retrieval, in SIGIR, pp. 2-10, ACM (1998)

[Turpin 07] Turpin, A., Tsegay, Y., Hawking, D., and Williams, H. E.: Fast generation of result snippets in web search, in SIGIR '07: Proceedings of the 30th annual international ACM SIGIR conference on Research and development in information retrieval, pp. 127-134, New York, NY, USA (2007), ACM

[Vaid 05] Vaid, S., Jones, C. B., Joho, H., and Sanderson, M.: 
表 9 出力結果例

\begin{tabular}{|c|c|c|c|}
\hline クエリ & 手法 & 出力 & $\begin{array}{l}\text { 指示性判定 } \\
\text { 結果 }\end{array}$ \\
\hline うどん & AS_COOR_D & $\begin{array}{l}\text { 結なので、天気が悪い日でも安心。小樽と札幌の境目にある }{ }^{\circledR K u f u u(ク ~} \\
\text { フウ)』に...「スープカリー坦々麺」や「スープカリーうどん」といっ } \\
\text { た、変り種のメニューがあり、... Curry Kufuu's*札幌市中央区大通西 } \\
5 \text { 丁目 昭和ビル地下 } 1 \text { 階 }\end{array}$ & $\begin{array}{l}\text { 閲覽すべき } \\
\text { (正解) }\end{array}$ \\
\hline 札幌 & AS_STRING & $\begin{array}{l}\text { 最後までとても美味しく頂けました。満腹、満足 ১このお店、「カリー } \\
\text { がゆ」の他にも、「スープカリー坦々麺」や「スープカリーうどん」と } \\
\text { いった、変り種のメニューがあり、気になるので、ぜひ、また、足を } \\
\text { 運びたいと思っています。々お得情報々「ぐるなび」、 }\end{array}$ & $\begin{array}{l}\text { 閲覧すべき } \\
\text { でない (不 } \\
\text { 正解) }\end{array}$ \\
\hline ハンバーグ & AS_COOR_D & $\begin{array}{l}\text { れはレディースセット。レディースっちゆうか、量多すぎっ。ハンバー } \\
\text { グも食べ応えあるつ。私は同僚と飲み物もう一個頼んでシェア...つと } \\
\text { してくれるとはげみになります。人気 blog ランキング (北海道) }\end{array}$ & $\begin{array}{l}\text { 閲覽すべき } \\
\text { でない (不 } \\
\text { 正解) }\end{array}$ \\
\hline 札幌 & AS_STRING & $\begin{array}{l}\text { ースセットだったり、パスタ、カレー等の軽食も弚ろっている。これ } \\
\text { はレディースセット。レディースっちゅうか、量多すぎっ。ハンバー } \\
\text { グも食へ応えあるっ。私は同僚と飲み物もう一個頼んでシェア。官公 } \\
\text { 庁食堂巡り、あとは、道庁最上階喫茶、区民センター食堂、 }\end{array}$ & $\begin{array}{l}\text { 閲覽すべき } \\
\text { (正解) }\end{array}$ \\
\hline
\end{tabular}

Spatio-textual Indexing for Geographical Search on the Web, in Medeiros, C. B., Egenhofer, M. J., and Bertino, E. eds., SSTD, Vol. 3633 of Lecture Notes in Computer Science, pp. 218-235, Springer (2005)

[Varadarajan 06] Varadarajan, R. and Hristidis, V.: A system for query-specific document summarization, in CIKM '06: Proceedings of the 15th ACM international conference on Information and knowledge management, pp. 622-631, New York, NY, USA (2006), ACM

[Zamir 99] Zamir, O. and Etzioni, O.: Grouper: a dynamic clustering interface to Web search results, Comput. Netw., Vol. 31, No. 11-16, pp. 1361-1374 (1999)

[Zhou 05] Zhou, Y., Xie, X., Wang, C., Gong, Y., and Ma, W.-Y.: Hybrid index structures for location-based web search, in CIKM '05: Proceedings of the 14th ACM international conference on Information and knowledge management, pp. 155-162, New York, NY, USA (2005), ACM

[安田 08] 安田 宜仁, 戶田 浩之 : 検索位置のごく周辺を対象とし た地理情報検索, 人工知能学会論文誌, Vol. 23, No. 5, pp. 364-373 (2008)

\section{〔担当委員 : 高山 泰博〕}

2009 年 3 月 30 日 受理

$$
\diamond \text { 付 録 } \diamond
$$

\section{A. $\alpha, \beta$ の設定基準}

4 章で述べた, テキスト断片中のキーワードの位置によりテキス 卜断片のスコアを調整するパラメータ $\alpha$ およびスニペット中の断 片数に応じてスニペット候補のスコアを減衰するパラメータ $\beta$ の 設定基準について示す

まず $\alpha$ につて示すため, スニペットを構成するテキスト断片候 補の例を図 A.1 に示す. (A) は一つのキーワードが中心位置に存在 するテキスト断片を示し, (B) は二つのキーワードが両端に存在す るテキスト断片を示す. 我々は,スニペットを構成するテキスト断片 にはより多くの検索条件に関係するキーワードを含むべきであると 考えている. 図 A.1 に示した例の場合には, 我々は (B) を (A) より 優先したい. しかしながら, どのような状況においても多くのキー ワードを含むテキスト断片を優先する $\alpha$ を特定するためには, スニ ペット長, キーワード長など樣々な要素を考慮する必要があり,かつ
検索条件や文書によって変化する条件の影響も受けるため, 厳密な 値を一つ設定するということはできない. 乥こで, ここでは少なく とも図 A.1 に示したように, (A) キーワードが一つ含まれるテキス 卜断片と (B) 二つ含まれるテキスト断片がある場合には (B) を優先 する事を考える. キーワード長を一定と考えれば, 図 A.1(A) はキー ワードを一つだけ含む状況で最大のテキスト断片スコアを示し, 図 A.1(B) はキーワードを二つ含む状況で最小のテキスト断片スコアを 示すので, 常に (B) のテキスト断片スコアを (A) のテキスト断片ス コアより大きくする $\alpha$ を設定できれば, 少なくともキーワードを二 つ含むテキスト断片をキーワードを一つしか含まないテキスト断片 より優先することができる.

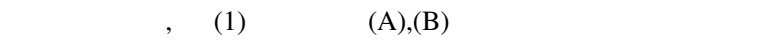
スコア $S_{A}\left(Q c, l, x_{1}\right), S_{B}\left(Q c, l . x_{2}\right)$ を算出する場合, 以下が成り立 つような $\alpha$ を設定しなければならない。

$$
S_{A}\left(Q c, l, x_{1}\right)<S_{B}\left(Q c, l . x_{2}\right)
$$

(A) では $\operatorname{mid}\left(l, x_{1}\right)=k w d \_m i d\left({ }^{\prime} K W D^{\prime}\right)$ が成り立つため以下 の通りとなる.

$$
S_{A}\left(Q c, l, x_{1}\right)=1
$$

また, (B) では以下のようになる.

$$
\begin{aligned}
& \mid \operatorname{mid}\left(l, x_{2}\right) \text { - kwd_mid }\left({ }^{\prime} K W 1^{\prime}\right) \mid=l / 2-\operatorname{length}\left({ }^{\prime} K W 1^{\prime}\right) / 2 \\
& \mid \operatorname{mid}\left(l, x_{2}\right) \text { - kwd_mid }\left({ }^{\prime} K W 2^{\prime}\right) \mid=l / 2-\operatorname{length}\left({ }^{\prime} K W 2^{\prime}\right) / 2
\end{aligned}
$$

以上より, 以下の通りとなる.

$$
\begin{aligned}
& S_{B}\left(Q c, l, x_{2}\right) \\
&> \alpha+(1-\alpha) \cdot\left(1-\frac{l / 2-\text { length }\left({ }^{\prime} K W 1^{\prime}\right) / 2}{l / 2}\right) \\
&+\alpha+(1-\alpha) \cdot\left(1-\frac{l / 2-\text { length }\left({ }^{\prime} K W 2^{\prime}\right) / 2}{l / 2}\right) \\
&= \alpha \cdot\left(2-\left(\frac{\text { length }\left({ }^{\prime} K W 1^{\prime}\right)}{l}+\frac{\text { length }\left({ }^{\prime} K W 2^{\prime}\right)}{l}\right)\right) \\
&+\left(\frac{\text { length }\left({ }^{\prime} K W 1^{\prime}\right)}{l}+\frac{\text { length }\left({ }^{\prime} K W 2^{\prime}\right)}{l}\right) \\
&= \alpha \cdot(2-\xi)+\xi
\end{aligned}
$$

ここで $\xi=$ length $\left({ }^{\prime} K W 1^{\prime}\right) / l+$ length $\left({ }^{\prime} K W 2^{\prime}\right) / l$ である. 
(A)

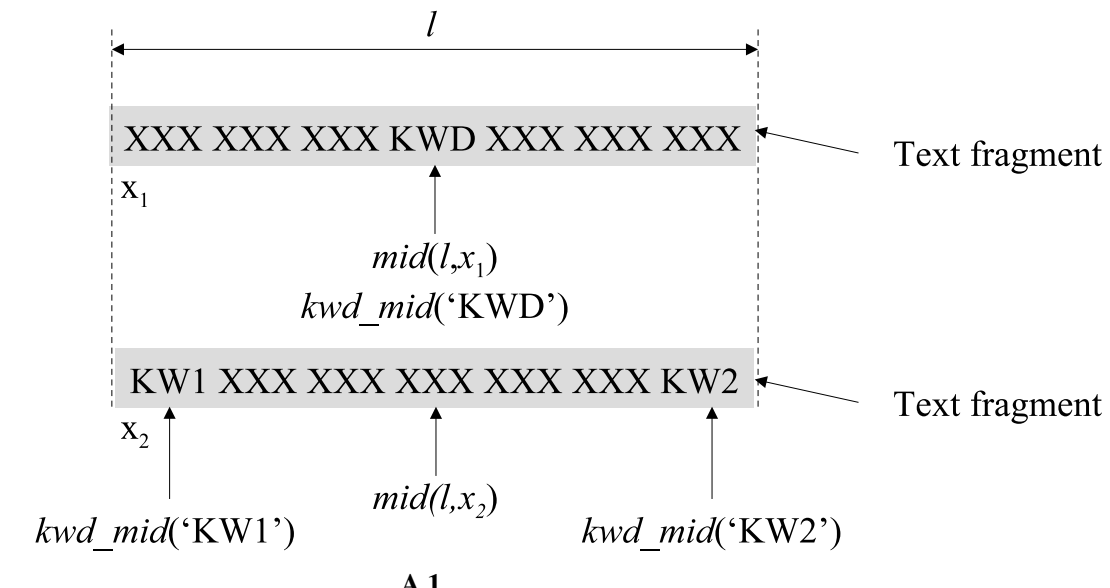

(C)

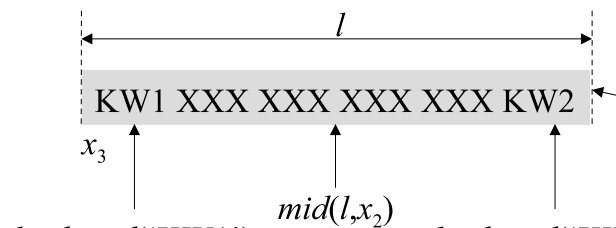

Snippet candidate consists of a fragment

Snippet candidate consists of two fragments
上記の式 (A.1) に式 (A.2) と式 (A.3) を代入し, 整理すると以下の 通りとなる.

$$
\alpha>\frac{1-\xi}{2-\xi}
$$

$1 \leq$ length $\left({ }^{\prime} K W 1^{\prime}\right) \leq l / 2,1 \leq$ length $\left(' K W 2^{\prime}\right) \leq l / 2,2 \leq l<\infty$ であることから, $0<\xi<1$ となる. この条件の元, 式 (A.4)を常に 満たすためには $\alpha \geq 0.5$ とする必要がある.

また, $\alpha$ がテキスト断片中のキーワードの位置に応じてスコアを ディスカウントするためのパラメータであることから $\alpha$ は以下の ように設定することとする.

$$
0.5 \leq \alpha<1
$$

次に $\beta$ について示すため, スニペット候補の例を図 A.2 に示す. (C) は二つのキーワードが両端に存在する二つのテキスト断片から なるスニペットの候補を示し, (D) は一つのキーワードが中心位置 に存在する二つのテキスト断片からなるスニペットの候補を示す.

我々の基本的な考えは, スニペットに含むキーワード数が同一で あれば, スニペットを構成するテキスト断片が少ない方を優先する というものである. これは断片数を多くした場合, スニペットが短い テキスト断片の集まりとして構成され, 内容の一貫性が保てない可 能性が高いと考えたためである.

しかし, $\alpha$ の場合と同樣に, どのような状況においても上記の考え を満たすパラメータ值 $(\beta)$ を設定するためには, スニペット長, テキ ス卜断片長など樣々な要素を考慮する必要があり, また検索条件や 文書によって変化する条件の影響も受けるため, 厳密な值を一つ設 定することができない.

弚こで,ここでは少なくとも図 A.2 の場合に (C) を優先する事を 考える. スニペットとして含むキーワードの数を二つとし, 乥れら キーワード長を一定と考れば図 A.2(C) はテキスト断片一つだけで 構成されるスニペットとしては最小のスニペットスコアを示し, 図
A.2(D) は二つのテキスト断片から構成されるスニペットとしては 最大のスコアを示す. ここで常に (C) のスコアを (D) のスコアより 大きくする $\beta$ を設定できれば, 二つのキーワードをカバーできるテ キスト断片が存在する場合, 弚のテキスト断片によるスニペットを 優先する事ができる.

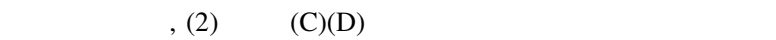
ア $S d_{C}(Q c, 1), S d_{D}(Q c, 2)$ を算出した場合に, 以下が成り立つ $\beta$ を設定しなければならない。

$$
S d_{C}(Q c, 1)>S d_{D}(Q c, 2)
$$

(C) の場合は, (B) のテキスト断片をスニペット候補にするもので あり, スコア $S d_{C}(Q c, 1)$ は以下のように表される.

$$
\begin{aligned}
& S d_{C}(Q c, 1) \\
&= S\left(l, x_{3}\right) \cdot \beta \\
&=\left(\alpha \cdot\left(2-\left(\frac{\text { length }\left({ }^{\prime} K W 1^{\prime}\right)}{l}-\frac{\text { length }\left({ }^{\prime} K W 2^{\prime}\right)}{l}\right)\right)\right. \\
&\left.+\left(\frac{\text { length }\left({ }^{\prime} K W 1^{\prime}\right)}{l}+\frac{\text { length }\left({ }^{\prime} K W 2^{\prime}\right)}{l}\right)\right) \cdot \beta \\
&=(2 \alpha+(1-\alpha) \cdot \xi) \cdot \beta
\end{aligned}
$$

ここで, $\xi=$ length $\left({ }^{\prime} K W 1^{\prime}\right) / l+$ length $\left({ }^{\prime} K W 2^{\prime}\right) / l$ である.

一方, (D) の場合は, $\operatorname{mid}\left(l, x_{4}\right)=k w d \_m i d\left({ }^{\prime} K W 1^{\prime}\right), \operatorname{mid}\left(l, x_{5}\right)=$ $k w d \_m i d\left({ }^{\prime} K W 2^{\prime}\right)$ が成り立つため以下の通りとなる.

$$
\begin{aligned}
& S d_{D}(Q c, 2) \\
& =\left(S\left(l, x_{4}\right)+S\left(l, x_{5}\right)\right) \cdot \beta^{2} \\
& =(1+1) \cdot \beta^{2}=2 \beta^{2}
\end{aligned}
$$


式 (A.5) に式 (A.6) と式 (A.7) を代入し, 整理すると以下の通りと なる。

$$
\beta<\alpha+\frac{1-\alpha}{2} \cdot \xi
$$

ここで, 上式の右辺を $f(\alpha, \xi)$ とおく $.1<$ length $\left({ }^{\prime} K W 1^{\prime}\right)<l / 4,1<$ length $\left({ }^{\prime} K W 2^{\prime}\right)<l / 4,2<l<\infty$ であることから $0<\xi<1 / 2$ で ある. 乥して, $f(\alpha, 0)=\alpha, f(\alpha, 1 / 2)=1 / 4+3 / 4 \cdot \alpha$ であり, 上記 で示した $0.5 \leq \alpha<1$ では $f(\alpha, 0)<f(\alpha, 1 / 4)$ となることから, $f(\alpha, \xi)$ の値域は以下のようになる.

$$
\alpha<f(\alpha, \xi)<1 / 4+3 / 4 \cdot \alpha
$$

式 (A.8) および (A.9) から, $\beta$ は以下のように設定することとする.

$$
\beta \leq \alpha
$$

\section{著 者紹 介}

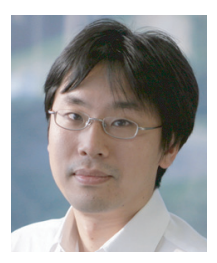

戸田 浩之(正会員)

1997 年名古屋大学工学部材料プロセス工学科卒業. 1999 年同大大学院工学研究科博士課程前期課程修了. 同年, 日 本電信電話 (株) 入社 . 2007 年筑波大学大学院システム情 報工学研究科博士後期課程修了. 現在, NTT サイバーソ リューション研究所勤務 . 情報検索, 情報抽出, Web マイ ニングの研究に従事，博士 (工学) . ACM SIGIR，情報処 理学会, 電子情報通信学会, 日本データベース学会各会員.

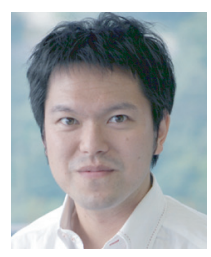

\section{安田 宜仁(正会員)}

1997 年京都大学大学総合人間学部基礎科学科卒業 . 1999 年同大大学院人間・環境学研究科修士課程修了. 同年, 日 本電信電話 (株) 入社 . 現在, NTT サイバーソリューショ ン研究所勤務. 音声対話システム, 自然言語処理の研究に 従事.日本音響学会会員

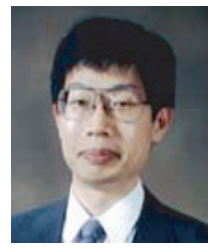

\section{奥村 学(正会員)}

1962 年生. 1984 年東京工業大学工学部情報工学科卒業。 1989 年同大学院博士課程修了. 同年, 東京工業大学工学 部情報工学科助手. 1992 年北陸先端科学技術大学院大学 情報科学研究科助教授, 2000 年東京工業大学精密工学研 究所助教授, 2009 年同教授, 現在に至る.工学博士.自 然言語処理, 知的情報提示技術, 語学学習支援, テキスト 評価分析, テキストマイニングに関する研究に従事.情報 処理学会, AAAI, 言語処理学会, ACL, 認知科学会, 計量

国語学会各会員.

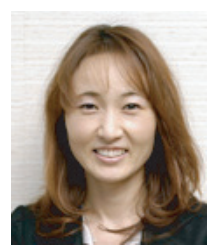

\section{松浦 由美子}

1993 年慶應義塾大学大学院計算機科学科修士課程修了. 同 年日本電信電話株式会社に入社 . 以来 , 音楽データの特街 部分抽出の研究, 電子透かしシステムの研究開発, コンテ ンツ流通システムの研究開発, ポータルサービスシステム の研究開発に従事. 現在, NTT サイバーソリューション 研究所所属. 情報処理学会会員.

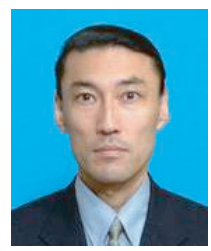

\section{片岡 良治}

1987 年千葉大学大学院電子工学専攻修士課程修了. 同年 日本電信電話株式会社に入社. 以来, トランザクションの 並行処理制御方式の研究, マルチメディア情報システムの 研究, ポータルサービスシステムの研究開発に従事 . 現在, NTT サイバーソリューション研究所所属 . 情報処理学会 会員. 